\title{
Maternal Beslenmenin Yavrular Üzerine Etkileri: Fetal Programlama ve Epigenetik Mekanizmalar
}

\author{
Effects of Maternal Nutrition on Offspring: Fetal Programming and Epigenetic Mechanisms
}

\author{
Sabriye Arslan', Hilal Yıldıran ${ }^{2}$
}

Geliş tarihi/Received: 21.01.2021 • Kabul tarihi/Accepted: 24.03.2021

\section{ÖZET}

Maternal beslenme birçok bulaşıcı olmayan kronik hastalığın gelişiminde belirleyici bir rol oynamaktadır. Gebelik boyunca maternal beslenme durumu programlanmada değişikliklere neden olup yetişkin dönem hastalıklarının gelişimine katkıda bulunabilir. Plasenta yetmezliği, glukokortikoidlere maruz kalma, beslenme yetersizlikleri ya da fazlalıkları ve stres gibi çeşitli perinatal sorunlar ile birlikte maternal intestinal mikrobiyom fetusun/yavrunun gelişimini değiştirerek kronik bulaşıcı olmayan hastalıkların oluşmasında yatkınlığa yol açabilir. Aynı zamanda gebelik sürecince yapılan beslenme müdahaleleri, programlama sürecinin tersine çevrilerek bulaşıcı olmayan hastalıkların önlenmesini amaçlayan yeni stratejilerin oluşturabilmesi için çok değerlidir. Fetal gelişim sırasında gen ekspresyonu epigenetik mekanizmalardan etkilenebilir. Özellikle deoksiribonükleik asit metilasyonunda rol alan genlerin epigenetik modifikasyonları, histon modifikasyonları ve mikroRNA'lar hayatın sonraki dönemlerinde metabolik hastalıkların gelişimine katkıda bulunabilir. Bu derlemede epidemiyolojik çalışmalar ve hayvan modellerinden elde edilen veriler ışığında maternal beslenmenin fetal programlama üzerine etkilerinin altında yatan mekanizmalardan biri olan epigenetik mekanizmalar ele alınmıştır.

Anahtar kelimeler: Fetal programlama, epigenetik, maternal beslenme

\begin{abstract}
Maternal nutrition plays a decisive role in the development of many non-communicable diseases. Maternal nutritional status during pregnancy can contribute and program the development of adult diseases. Along with various perinatal problems such as placental insufficiency, glucocorticoid exposure, nutritional deficiencies or excesses, and stress and the maternal intestinal microbiome may alter the development of the fetus/offspring, leading to a predisposition to the development of chronic non-communicable diseases. At the same time, nutritional interventions during pregnancy are very valuable for reversing the programming process and creating new strategies aimed at preventing non-communicable diseases. Gene expression can be affected by epigenetic mechanisms during fetal development. Epigenetic modifications of genes involved in deoxyribonucleic acid methylation, histone modifications and microRNAs may contribute to metabolic diseases later in life. In this review, epigenetic mechanisms, one of the mechanisms underlying the effects of maternal nutrition on fetal programming,were discussed in the light of data obtained from epidemiological studies and animal models.
\end{abstract}

Keywords: Fetal programming, epigenetic, maternal nutrition

1. İletişim/Correspondence: Gazi Üniversitesi, Sağlık Bilimleri Fakültesi, Beslenme ve Diyetetik Bölümü, Ankara, Türkiye

E-posta: sabriyebolluk@hotmail.com • • https://orcid.org/0000-0002-9068-4009
2. Gazi Üniversitesi, Sağlık Bilimleri Fakültesi, Beslenme ve Diyetetik Bölümü, Ankara, Türkiye • • https://orcid.org/0000-0001-7956-5087 


\section{GİRIŞ}

Maternal beslenme fetal büyüme ve gelişmede kritik bir belirleyicidir (1). Gebelik sırasındaki olumsuz beslenme koşullarının yavruların karaciğer, pankreas, böbrek, kalp, kas gibi birtakım organların yapısını ve işlevini kalıcı olarak değiştirerek birçok yetişkin hastalığına yol açabileceği uzun zamandır bilinmektedir (2). Fetal programlama kavramı ilk olarak 1998'de Barker ve Hales tarafindan önerilmiş ve daha sonra Sağlık ve Hastalığın Gelişimsel Kökenleri (Developmental Origins of Health and Disease -DOHaD) teorisi haline gelmiştir (2). Bu teori olumsuz rahimiçi ortamın neden olduğu fetal metabolik programlamanın yavrularda yetişkin dönemdeki metabolik hastalıkları indüklediğini ileri sürmektedir. Fetal metabolik programlama, büyüme ve gelişmedeki metabolik sinyal yollarının nispeten kalıcı değişikliklerinde rol oynar. Fetal büyüme ve gelişmenin yapısı ve/veya fonksiyonel değişiklikleri üzerinde geri dönüşü olmayan etkilere yol açabilir (3).

Gebelik sırasındaki beslenme müdahaleleri DOHaD ile ilişkili hastalıkların önlenmesinde önem kazanmaya başlamıştır. Vücudun yaşamın ilerleyen dönemlerinde zorluklara tepki verme şeklini belirleyen, gelişmekte olan organların plastisitesi nedeniyle erken yaşamda maruz kalınan beslenme durumu oldukça önemlidir (4). Diyet bileşenleri ile uterusta genomun yeniden düzenlenmesi arasındaki ilişkinin keşfi ve yaşamın ilk aşamalarında epigenetik programlamanın başlatılmasının sonraki aşamalarda organizmanın fenotipini kalıcı olarak değiştirebileceği gerçeği heyecan verici bir bulgudur (5).

$\mathrm{Bu}$ derlemede maternal beslenmenin yavruların sağlığı üzerindeki etkileriyle ilgili olarak olası mekanizmalardan olan epigenetik mekanizmalar ve maternal beslenmenin bu mekanizmalar üzerine etkileri incelenmiştir.

\section{Hastalık ve Sağlığın Gelişimsel Programlanması ve Beslenmeyle İlişkisi}

Beslenmeyle ilgili programlama terimi, yaşamın erken dönemindeki beslenme şekillerinde farklılıklara maruz kalmanın, morfolojik değişikliklere veya yavrularin fonksiyonel adaptasyonuna neden olduğu süreci tanımlar (6). Beslenme uyaranlarının uzun vadeli sonuçları değişken olup, bu sonuçlar farklı beslenme şekillerine maruz kalma süresi ve yoğunluğu, besin ögesi türü, uygulandığı gebelik dönemindeki kritik zaman aralıkları ve cinsiyet gibi çeşitli faktörlere bağlıdır (6).

Perinatal dönemde ortamda maternal besin ögesi değişkenliği (yetersiz/fazla beslenme), hormonal değişiklikler, maternal stres ve plasenta disfonksiyonu gibi durumlar söz konusu olabilir ve bu faktörler farklı dokular, organlar ve insan vücudunun genel işlevleri üzerinde uzun süreli zararlı etkilere yol açabilir (7). $\mathrm{Bu}$ zararlı etkilerin gelişiminin yetişkinlikte risk faktörleri ve genler arasındaki etkileşime, genler ile fetal embriyo arasındaki etkileşime ve doğum sonrası erken dönemde çevreye bağlı olduğu öne sürülmüştür (5). Belirli bir besin ögesinin aşırı veya yetersiz alımı çeşitli bulaşıcı olmayan hastalıkların gelişimsel programlamasıyla ilişkilendirilmektedir. İyi bilinen bir örnek gebelikte yetersiz beslenmenin koroner kalp hastalığı, hiperlipidemi, obezite, obstrüktif hava yolu hastalığı, böbrek hastalığı ve hipertansiyon geliştirme riskinin artmasıyla ilişkili olduğunu gösteren Hollanda kıtlığı çalışmasıdır (8). Bu çalışmada kıtlığa maruz kalınan gebelik dönemine göre farklı organların etkilendiği bildirilmiştir (8). Örneğin gebeliğin orta döneminde kitlığa maruz kalınması obstrüktif hava yolu hastalıkları ve mikroalbuminüri ile ilişkili iken; gebelik sonlarında kıtlığa maruz kalınması glikoz toleransında azalma ile ilgili bulunmuştur (8). Ancak Leningrad kuşatma kıtlığı çalışmasında benzer bir sonuç gözlenmemiştir (9). İki çalışma arasındaki farklılığın temel nedeni doğum sonrası dönemdeki beslenme farklılıkları olup doğum sonrası dönemde Hollanda'daki beslenme koşullarının Leningrad kuşatma kıtlığına göre daha kısa sürede iyileşmesidir (9). Bu nedenle özellikle doğum sonrası erken dönemde beslenme koşulları yeterli olduğunda rahimiçi malnütrisyonun daha büyük etkiler oluşturabileceği vurgulanmıştır (9). 
Kıtlı̆̆a maruz kalmanın oluşturduğu farklı etkiler kıtlığa maruz kalınan gebelik döneminin, bu dönemde gelişen organ ve sistemler ile birlikte doğum sonrası beslenme koşullarının önemini ortaya koymaktadır (6).

Thrifty (tutumlu) fenotip hipotezi yetersiz fetal beslenme durumunda yavrunun hayatta kalma şansını en üst düzeye çıkarmak için fetal dönemde hayati organların gelişimi sırasında kalıcı metabolik adaptasyonların meydana geldiğini öne sürmektedir $(10,11)$. Yetersiz maternalbeslenmenefronlar, kalpkası hücreleri ve pankreas hücreleri gibi kritik organların hücre sayısında ve fonksiyonel kapasitelerinde azalmalara yol açabilir (7). $\mathrm{Bu}$ değişikliklerin oluşması doğum sonrası yaşamda besin ögesi eksikliği durumunda hayatta kalmayı sağlar (7). Ancak tersine doğumdan sonra bol miktarda besin ögesi varlığı söz konusu olduğunda doğum öncesi ve doğum sonrası ortamlar arasindaki uyumsuzluk nedeniyle uzun vadeli zararlı etkiler ortaya çıkar (11). Fetüse artan besin tedarikinin metabolik programlama nedeniyle postnatal dönemde daha fazla enerji alımına neden olabileceği belirtilmiştir. Nöroendokrin faktörlerdeki değişikliklere bağlı olarak artan fetal enerji alımı ve adipozite, doğumdan sonra besin tercihlerini ve vücut kompozisyonunu değiştirir (12). Maternal beslenme metabolik anormalliklere yol açan epigenetik mekanizmalarla fetal gen ekspresyonunu kalıcı olarak etkileyebilir ve bu epigenetik modifikasyonlar kuşaklararası kalıtım nedeniyle uzun vadeli sonuçlara sahip olabilir (7).

\section{Maternal Beslenme ve Hastalıkların Gelişimsel Programlanmasının Altında Yer Alan Epigenetik Mekanizmalar}

Maternal beslenme ve hastalıkların gelişimsel programlaması üzerine olası birtakım mekanizmalar öne sürülmüştür. Bunlardan ilki besin ögesine duyarlı sinyaller aracılığıyla maternal beslenme durumuna göre fetal metabolizma ve gelişimin belirlenebileceğidir (13). İkincisi ise gebelikte oksidatif stresin hassas organlar üzerinde yaşam boyu kalıcı etkilere yol açarak ilerleyen yıllarda yavruda olumsuz sağlık sonuçlarına yol açabileceğidir (14). Ayrıca gebelikte beslenme ile değişikliklere maruz kalınan dönem doku yeniden modellemesine neden olabilir (6). Plasentanın maternal-fetal beslenme bileşimini ve arzını düzenlemesi nedeniyle maternal beslenmenin fetüse önemli sinyallerin taşınmasını etkileyen plasental gen ekspresyonunda değişikliklere neden olabileceği belirtilmektedir (10). Hastalıkların gelişimsel programlanmasında erken yaşam bağırsak mikrobiyotasının rolünü öne süren kanitlar da artmaktadir (15).

Yetişkin hastalıklarının intrauterin programlama mekanizmalarının aydınlatılması için son yıllarda bu mekanizmalara ek olarak gündeme gelen epigenetik düzenlemeler de söz konusudur. Epigenetik, DNA nükleotid dizisinde değişiklik olmaksızın gen ekspresyonundaki varyasyonun kalitımıdır (16). Epigenetik modifikasyon hücre proliferasyonu sürecinde nispeten istikrarlı bir şekilde iletilebilir (3). Son yıllarda epigenetik mekanizmalar aracılığıyla değişen gen ekspresyonlarının birtakım sağlık sorunlarına yol açabileceği düşünülmektedir (16). Epigenetik programlama kavramı, epigenetik modifikasyonun fetal metabolik programlamadaki potansiyel anahtar rolü olarak önerilmiştir (17). Bilinen mekanizmalar arasında DNA metilasyonu, histon modifikasyonu, genomik baskllanma (imprinting), kromatin yeniden modelleme, kodlamayan RNA yer almaktadır (3). DNA metilasyonu, histon modifikasyonları, mikroRNA varyasyonları ile ilgili fetal dönemdeki genlerin epigenetik modifikasyonları, yaşamın sonraki dönemlerinde metabolik bozukluklara katkıda bulunabilir (18). Epigenetik mekanizmalar beslenme de dâhil olmak üzere maternal, plasental ve fetal faktörler gibi durumlardan etkilenmektedir (19).

\section{DNA Metilasyonu}

DNAmetilasyonuyaygmbirmodifikasyondur(20).DNA metilasyonu hücre gelişiminin, hücre homeostazının ve hücre fonksiyonlarının, gen ekspresyonu kontrolünün, tekrarlayan DNA elemanlarının susturulmasının, genomik baskılamanın ve kromatin 
yapının düzenlemesinde rol oynar (21). Normal hücrelerde DNA metilasyon seviyesi iyi bir şekilde dengelenmiştir; ancak bireysel olarak genomik bölgelerdeki epigenetik modifikasyonlar genetik ve çevresel faktörlerden etkilenmektedir (21). Maternal beslenme faktörleri DNA metilasyonunu etkiler (15). Beslenmenin tek karbon metabolizması yoluyla genomik DNA metilasyonu üzerindeki etkisi net bir şekilde açıklanmıştır (20).

\section{Histon Modifikasyonu}

Histon modifikasyonları karmaşık bir epigenetik mekanizmadır (22). Bu epigenetik modülasyon hücre içindeki kromatin yapısını, erişilebilirliği ve transkripsiyon aktivitelerini düzenler (5). Histon modifikasyonları, kromatinin yapısını ve işlevini etkiler; böylece lokalize genlerin ekspresyonunu düzenler $(3,20)$. Histon modifiye edici enzimler histon kuyruklarında epigenetik işaretler ekler veya çıkarırlar (7). Bu enzimler histon metiltransferazlar veya demetilazlar ile histon asetiltransferazlar veya deasetilazlardır. Transkripsiyon faktörleri genlere bağlanarak histon asetiltransferaz enziminin aracılık ettiği ekspresyonlarının artmasını destekler ve histon deasetilaz enzimi deasetilasyon sürecine aracılık eder (7). Maternal diyetin yağ içeriği, glisemik yükü gibi birtakım faktörler fetüsün histon modifikasyonları üzerinde değişikliğe yol açarak kronik hastalık riskini etkileyebilir (23). Yapılan bir çalışmada maternal yüksek yağlı diyet (High Fat Diet-HFD)'in belirli genlerin ekspresyonunlarını modüle edebilen, yavruların hipokampusundaki histon $\mathrm{H} 4$ asetilasyon durumunda değişikliklere neden olabildiği belirlenmiştir (24). Maternal HFD’nin yenidoğan karaciğer metabolizmasını histonların epigenetik modifikasyonu ile etkilediği ve gelişen yavrularda metabolik komplikasyonlara yol açtığı belirtilmiştir (25). Ayrıca maternal obezite asetilasyon sürecini etkileyen ve fetal gelişimi olumsuz etkileyebilen başka bir faktördür (26).

\section{RNA Temelli Modifikasyonlar}

İnsan genomu toplam genomun \%2'sinden azını temsil eden yalnızca 20.000 protein kodlayan gen içerirken; insan genomunun önemli bir fraksiyonu sinırlı protein kodlama kapasitesine sahip birçok kısa veya kodlamayan RNA (ncRNA) vererek kopyalanabilir (20). Bunlar arasında en kapsamlı çalışılan ncRNA’lar evrimsel olarak korunan ve protein kodlayan genlerde bulunan mikroRNA'lardır (miRNA'lar) (20). DNA metilasyonu ve histon modifikasyonlarma ek olarak miRNA'lar maternal obezite ve beslenmeden etkilenebilecek potansiyel üçüncü epigenetik mekanizmadır (7). miRNA'lar gen ekspresyonunun transkripsiyon sonrası düzenlenmesinde işlev gören küçük kodlamayan RNA molekülleridir (15). Diyet faktörlerinin miRNA ekspresyon profillemesini, özellikle lipid metabolizması değişiklikleri, insülin direnci ve inflamasyon ile yavrularda maternal beslenmeyle indüklenen epigenetik modifikasyonları modifiye ettiği gösterilmiştir (20). miRNA'lar farklılaşma, hücre proliferasyonu ve enerji metabolizması dâhil olmak üzere biyolojik süreçlerin düzenlenmesinde rol oynar (15). Bir gebelik kohort çalışmasında miRNA'ların ekspresyonunun gebelik öncesi beden kütle indeksi ile pozitif ilişkili olduğu belirlenmiş olup; miRNA'ların çoğunun adipogenez ile ilişkili olduğu vurgulanmıştır (27).

\section{Maternal Beslenmenin Epigenetik Mekanizmalara Etkileri}

Maternal aşırı beslenme ve HFD'ler yavruların epigenomunda DNA metilasyonunu, histon asetilasyonunu ve histon metilasyonunu değiştirerek adipogenezisle ilgili adiponektin, leptin, peroksizom proliferatör-aktive edici reseptör gama (PPAR- $\gamma$ ) gibi genlerde spesifik değişikliklere yol açabilir. Böylece doğum ağırlığında artışa neden olarak ilerleyen yıllarda metabolik hastalıkların gelişme riskini artırır (17). Primatlar üzerinde yapılan çalışmalar yüksek enerjili maternal diyetin epigenetik kovalent histon modifikasyonları yoluyla fetüsün kromatin yapısını da değiştirerek obezitenin epigenetik programlamasına yol açabileceğini bildirmiştir (17,28).

Hayvan modellerinde gebelik ve laktasyon sirasında annenin HFD ile beslenmesinin yavrularda metabolik sağlığın bozulmasına neden olduğu gösterilmiştir 
(7). Strakovsky ve Zhang (25) tarafından yapılan bir çalışmada, maternal HFD’nin yenidoğanda hepatik metabolizmayı cinsiyete özgü bir şekilde histon modifikasyonu aracılığıyla değiştirdiği gösterilmiştir. Maternal HFD’nin hepatik $\beta$-oksidasyonla ilişkili genlerin ve miRNA'ların ekspresyonunu modüle ederek, yavruların erken dönem lipid metabolizmasını etkilediği bulunmuştur (29). Maternal HFD’nin enerji dengesinin kontrolünde anahtar rol oynayan hipotalamik proopiomelanokortin geninde uzun vadeli epigenetik değişiklikleri programladığı da bildirilmiştir (30). Maternal HFD’ler beslenme davranışında değişikliklere neden olan dopamin ve opioid ile ilişkili genlerin metilasyonunu ve gen ekspresyonunu da değiştirebilir (21).

Hayvan modellerinde malnütrisyon olmaksızın enerji kısitlaması metilasyon ve mRNA ekspresyon modellerini ve kromatin yapısını etkiler; metabolizmayl, inflamasyonu ve yaşam süresini düzenler (31). Tam tersi, enerji kısıtlaması ve neden olduğu maternal malnütrisyonun yavrular üzerinde zararlı etkileri vardır (32). Maternal yetersiz beslenme DNA metilasyonu, histon modifikasyonu ve miRNA profilinde değişiklikleri indükler (17). Böylece adipogenezis ve metabolizmayla ilişkili genlerde değişikliğe yol açarak fetal rahimiçi büyümede geriliğe, insülin direncine ve diyabete yatkınlığı artırmaktadır (17). Besin ögesi fazlalığı veya eksikliği insülin ve leptin direnci dahil olmak üzere hipotalamik yolakların regülasyonunu kalıcı olarak değiştirebilir. $\mathrm{Bu}$ durum besin alımında ve ağırlık kazanımında kalıcı artışların temeli olabilir (20).

Fetal gelişim sırasında diğer önemli besin ögesi ise amino asitlerdir. Yetersiz protein içeren maternal diyetin glukokortikoid reseptör geni ve PPAR ekspresyonu üzerinde bir etkiye sahip olduğu bildirilmiştir (5). Düşük proteinli maternal diyet, fetüsün pankreasında farklı miRNA'ların artmış ekspresyonuna neden olarak insülin sekresyonu ve glukoz homeostazını etkilemiş ve tip 2 diyabete yatkınlığını artırmıştır (33). Yapılan bir çalışmada maternal düşük proteinli diyetin DNA metilasyonu ve miRNA'daki değişikliklerle yavruların beynindeki anjiyotensin dönüştürücü enzim-1'in ekspresyonunda ve mRNA düzeyinde önemli artışlara neden olduğu gösterilmiştir, bu durumun yetişkinlik döneminde hipertansiyonun ve diğer hastalıkların oluşumuna katkıda bulunabileceği vurgulanmıştır (34).

Bir diğer önemli nokta da DNA metilasyonunda yer alan metil donörü besin ögelerinin etkisidir. DNA metilasyonunda kullanılan metil grupları endojen sentez yoluyla ve daha da önemli olarak besinlerle vücuda alınmaktadır (23). Hücresel metilasyon reaksiyonları için gerekli metil grubu donörlerinin diyetsel yetersizliği veya fazlalığının epigenetik paternleri değiştirebileceği gösterilmiştir (7). Kolin, folik asit ve metiyoninin metil gruplarındaki karbonun S-adenosil metiyonin (SAM) metabolizması metil DNA, RNA ve proteinlere metil donör görevi görürken; B grubu vitaminleri bu epigenetik süreçte koenzim görevi görür (16). Maternal folat yetersizliği DNA metilasyonunda epigenetik değişikliklere neden olarak PPAR- $\gamma$ ve Peroksizom proliferatör aktive edici reseptör gamma koaktivatör-1 alfa'nın hiperasetilasyonunu uyarır (17). Böylece yavrularda insülin direnci, yüksek kan basıncı riski ve obeziteyle ilişkili metabolik hastalıkların riskini artırır (17). Fareler üzerinde yapılan çalışmalar aşırı miktarda folik asit, $\mathrm{B}_{12}$ vitamini, metiyonin, çinko, betain ve kolin gibi besin ögeleri verilen annelerden doğan farelerin değişmiş bir epigenoma sahip olduğunu göstermiştir (35). Gebelik sırasında maternal kolin desteğinin fetal karaciğer ve beyindeki histon modifikasyonuna ve DNA'nin metilasyonunun değişmesine neden olduğu gösterilmiştir (35). DNA metilasyonundaki rolü nedeniyle çinko, özellikle intrauterin yaşamda ve çocukluk çağında önemli rolleri vardır (36). Çinko eksikliği ileriki yaşlarda kronik hastalıkların gelişimini artırabilecek immün düzensizlik ile sonuçlanan promoter metilasyonunda değişikliğe katkıda bulunabilir (36).

Gebelik ve laktasyon döneminde yağ asidi alımındaki dengesizlikler fetüsteiştah kontrolünde,nöroendokrin fonksiyonda ve enerji metabolizmasında kalıcı değişikliklere neden olarak metabolik programlamaya yol açabilir (37). Yapılan bir çalışmada gebelik 
döneminde $400 \mathrm{mg} /$ gün dokozahekzaenoik asit (DHA) suplemantasyonunun, inflamatuvar genlerin DNA metilasyonunda değişiklikleri indüklediği belirlenmiştir (38). Karbonhidratların da epigenetik düzenlemede önemli bir rolü olduğu düşünülmektedir (39). Yapılan bir çalışmada, yüksek karbonhidratlı diyetin 21 günlük erkek rat yavrularının beyaz yağ dokusunda bazı lipojenik ve adipojenik genlerin yukarı regülasyonunu indüklediği bulunmuş olup bu durumun yavrularda obezite gelişimine neden olabileceği belirtilmiştir (39).

Epigenetik mekanizmalarla ilgili diğer besin ögeleri likopen, genistein, resveratrol, sülforafan, epigallokateşin-3-gallat (EGCG), kurkumin ve alil sülfür bileşikleri gibi fitokimyasallar olmakla birlikte bu fitokimyasallardan bazlarının epigenetik mekanizmalar üzerindeki etkileri henüz aydınlatılmamıştır (5). Maternal soya genisteini fetal epigenomda global modifikasyona yol açarak ektopik aguti gen ekspresyonunda hipermetilasyona yol açıp; fare yavrularında obezite prevalansını azaltmıştır (17). Sulforafan ise güçlü bir histon deasetilaz inhibitörü olarak görev yaparak epigenetik değişikliklere yol açabilir. Benzer şekilde EGGG da DNA metiltransferaz inhibitörü olup tümör baskılayıcı genleri metilasyonunu değiştirerek yavrularda kansere karşı koruma sağlayabilir (17). Probiyotikler de epigenetik yolakları etkileyerek kısa zincirli yağ asitleri ve bütirat gibi bağırsak mikrobiyotasının çeşitli metabolitlerinde değişikliklere yol açabilir (15). Gebelik sirasinda probiyotik suplemantasyonu, hem annelerin hem de yavruların obeziteyle ilişkili çeşitli promoterlerinin DNA metilasyonunu etkileyerek obeziteye karşı koruyucu olabilir (17).

Özetle maternal beslenme faktörleri epigenomu üç şekilde etkileyebilir. İlk olarak besin ögeleri histon N-terminal kuyruklarında kromatin ve lizin ve/veya arginin kalıntılarının yapısını yeniden modelleyebilir (40). Ayrica besin ögeleri S-adenosilmetiyonin (AdoMet) oluşumu için metil gruplarının sayısını doğrudan etkiler (17). Bunun yanı sıra besin ögeleri metiltransferaz aktivitesi ve DNA demetilasyon aktivitesindeki değişiklikleri içeren mekanizmalar yoluyla metil gruplarının kullanımını değiştirir (5). Ayrıca besin ögeleri folat-aracılı karbon metabolizması yolağındaki anahtar proteinlerin düzenlenmesinde rol oynayan miRNA ekspresyonunu değiştirebilir (21). Ayrıca bu yolak homosistein, metiyonin, B kompleks vitaminlerinin düzenlenmesinde ve proteinlerin, histonların, DNA ve RNA'nın metilasyonunda da rol oynar (21).

Maternal beslenmenin epigenetik mekanizmalar üzerindeki etkisini gösteren insan çalışmaları da her geçen gün artmakla birlikte, bu tür insan çalışmalarının zorlayıcı koşulları nedeniyle sayıları sinırlı kalmaktadır (23).

\section{SONUÇ VE ÖNERİLER}

Sonuç olarak besin ögelerifetal ve erken doğum sonrası gelişimin belirli önemli anlarında epigenetik süreçleri ve metabolik programlamayı modüle edebilir. Maternal diyet bir çocuğun genomu üzerinde ömür boyu devam eden bir etkiye sahip olabilir ve yetişkin dönemde hastalıkların gelişme riskini etkileyebilir. Epigenetik mekanizmaların temel özelliklerinden biri modülasyona yanıt verme yetenekleridir; bu durum uzun vadede ortaya çlkabilecek hastalık riskini değiştirmek için erken beslenme müdahalesini de mümkün kllabilmesidir. Beslenme değişiklikleri ile değiştirilen epigenetik süreçlerin belirlenmesi kronik hastalıkların tedavisinde mevcut sorunu ele almak için yeni stratejiler bulmaya yardımcı olabilir. $\mathrm{Bu}$ açıdan gebelik öncesi, gebelik ve laktasyon dönemlerinde sağlık parametrelerinin iyileştirilmesi oldukça önemlidir. Gebelik öncesi dönemde ideal vücut ağırlığının sağlanması ve gebelik dönemi boyunca uygun ağırlık kazanımının sağlanması gereklidir. $\mathrm{Bu}$ dönemlerde sağlıklı beslenme önerilerine uyulması yavruların yetişkin dönemdeki sağlıklarının iyileştirilmesine katkıda bulunabilir. Bu açıdan doğurganlık çağındaki kadınlarının her sağlık kontrolünün aslında gebelik öncesi bir dönem olarak değerlendirilmesi ve optimal sağllk hedeflerine ulaşılmaya çalışılması gerekmektedir. 
Enerji ve besin ögelerinin fazlalığı veya yetersizliği durumunun fetal programlama üzerinde oluşturduğu etkilerin daha iyi anlaşılması gerekmektedir. Diyet epigenetik modülatörlerinin transgenerasyon etkileri dahil genetik olarak özel, hastalığa yatkın bir organizma üzerindeki etkisi ve farklı diyet epigenetik modülatörlerinin kombine etkisi veya bir diyete kronik olarak maruz kalmanın etkilerinin daha iyi açıklanması gerekmektedir. Ayrıca bireysel polimorfizmi dikkate alan epigenom modülatörleri üzerine araştırma hala çok azdır. Gebelik veya laktasyon sirasında maternal diyetin besin ögesi bileşiminin yavrularda sağlık sonuçlarını etkilediği mekanizmaların anlaşılması maternal diyet önerilerinin iyileştirilmesine ve yavrular için daha iyi hastalık önleme stratejileri ve tedavilerinin geliştirilmesine yardımcı olabilir. $\mathrm{Bu}$ bağlamda beslenme programlamasının erken yaşam ve biyolojik işlevler üzerindeki etkisini daha iyi anlamak için daha fazla araştırmaya ihtiyaç vardır.

Çıkar çatışması - Conflict of interest: Yazarlar çıkar çatışması olmadığını beyan ederler. - The authors declare that they have no conflict of interest.

\section{KAYNAKLAR}

1. Tayhan Kartal Y, Helvacı G, Yabancı Ayhan N. Maternal beslenme ve ilerleyen yaşamda obezite. GÜSBD. 2020;9(1):36-8.

2. Barker DJ. In utero programming of chronic disease. Clin Sci. 1998;95(2):115-14.

3. Zhu Z, Cao F, Li X. Epigenetic programming and fetal metabolic programming. Front Endocrinol (Lausanne). 2019;10:764.

4. Parlee SD, MacDougald OA. Maternal nutrition and risk of obesity in offspring: The Trojan horse of developmental plasticity. Biochim Biophys Acta. 2014;1842(3):495-11.

5. Ramírez-Alarcón K, Sánchez-Agurto A, Lamperti L, Martorell M. Epigenetics, maternal diet and metabolic programming. Open Biol J. 2019;7(1):45-6.

6. Hsu CN, Tain YL. The good, the bad, and the ugly of pregnancy nutrients and developmental programming of adult disease. Nutrients. 2019;11(4):894.

7. Şanlı E, Kabaran S. Maternal obesity, maternal overnutrition and fetal programming: Effects of epigenetic mechanisms on the development of metabolic disorders. Curr Genomics. 2019;20(6):419-9.
8. Painter RC, Roseboom TJ, Bleker OP. Prenatal exposure to the Dutch famine and disease in later life: An overview. Reprod Toxicol. 2005;20(3):345-52.

9. Stanner SA, Yudkin JS. Fetal programming and the Leningrad Siege study. Twin Res. 2001;4(5):287-6.

10. Kwon EJ, Kim YJ. What is fetal programming? A lifetime health is under the control of in utero health. Obst Gynecol Sci. 2017;60(6):506-13.

11. Wellsnw JC. The thrifty phenotype hypothesis: Thrifty offspring or thrifty mother? J theor Biol. 2003;221:14318.

12. Desai M, Ross MG. Maternal-infant nutrition and development programming of offspring appetite and obesity. Nutr Rev. 2020;78(Supplement 2):25-6.

13. Efeyan A, Comb WC, Sabatini DM. Nutrient-sensing mechanisms and pathways. Nature. 2015;517(7534):3028.

14. Tan BL, Norhaizan ME, Liew W-P-P. Nutrients and oxidative stress: Friend or foe? Oxid Med Cell Longev. 2018;1-24.

15. Neri C, Edlow AG. Effects of maternal obesity on fetal programming: Molecular approaches. Cold Spring Harb Perspect Med. 2015;6(2):a026591.

16. Şurgun E. Maternal beslenmenin epigenetik mekanizmalar üzerinden infant sağllğına etkileri. BÜSBİD. 2019;1(1):1-17.

17. Li Y. Epigenetic mechanisms link maternal diets and gut microbiome to obesity in the offspring. Front Genet. 2018;9:342.

18. Stevenson K, Lillycrop KA, Silver MJ. Fetal programming and epigenetics. Curr Opin Endocr Metab Res. 2020;13:16.

19. Lillycrop K, Burdge G. Maternal diet as a modifier of offspring epigenetics. J Dev Orig Health Dis. 2015;6(2):887.

20. Lee HS. Impact of maternal diet on the epigenome during in utero life and the developmental programming of diseases in childhood and adulthood. Nutrients. 2015;7(11):9492-15.

21. Chango A, Pogribny IP. Considering maternal dietary modulators for epigenetic regulation and programming of the fetal epigenome. Nutrients. 2015;7(4):2748-22.

22. Goyal D, Limesand SW, Goyal R. Epigenetic responses and the developmental origins of health and disease. J Endocrinol. 2019;242(1):T105-T19.

23. Akyol Mutlu A. Maternal beslenme, tip 2 diyabet ve epigenetik. Bes Diy Derg. 2016;44(1):62-7.

24. Gawlinska K, Gawlinski D, Filip M, Przegalinski E. Relationship of maternal high-fat diet during pregnancy and lactation to offspring health. Nutr Rev. 2020;00(0):117. 
25. Strakovsky RS, Zhang X, Zhou D, Pan Y-X. The regulation of hepatic Pon1 by a maternal high-fat diet is gender specific and may occur through promoter histone modifications in neonatal rats. J Nutr Biochem. 2014;25(2):170-6.

26. Panchenko PE, Voisin S, Jouin M, Jouneau L, Prézelin A, Lecoutre S, et al. Expression of epigenetic machinery genes is sensitive to maternal obesity and weight loss in relation to fetal growth in mice. Clin Epigenetics. 2016;8(1):1-18.

27. Enquobahrie DA, Wander PL, Tadesse MG, Qiu C, Holzman C, Williams MA. Maternal pre-pregnancy body mass index and circulating microRNAs in pregnancy. Obes Res Clin Pract. 2017;11(4):464-10.

28. Aagaard-Tillery KM, Grove K, Bishop J, Ke X, Fu Q, McKnight R, et al. Developmental origins of disease and determinants of chromatin structure: Maternal diet modifies the primate fetal epigenome. J Mol Endocrinol. 2008;41(2):91-11.

29. Benatti R, Melo A, Borges F, Ignacio-Souza L, Simino L, Milanski M, et al. Maternal high-fat diet consumption modulates hepatic lipid metabolism and microRNA-122 (miR-122) and microRNA-370 (miR-370) expression in offspring. Br J Nutr. 2014;111(12):2112-10.

30. Gali Ramamoorthy T, Allen TJ, Davies A, Harno E, Sefton C, Murgatroyd C, et al. Maternal overnutrition programs epigenetic changes in the regulatory regions of hypothalamic Pomc in the offspring of rats. Int J Obes (Lond). 2018;42(8):1431-13.

31. Hernández-Saavedra D, Moody L, Xu GB, Chen H, Pan Y-X. Epigenetic regulation of metabolism and inflammation by calorie restriction. Adv Nutr. 2019;10(3):520-16.

32. Ong TP, Ozanne SE. Developmental programming of type 2 diabetes: Early nutrition and epigenetic mechanisms.
Curr Opin Clin Nutr Metab Care. 2015;18(4):354-6.

33. Alejandro EU, Gregg B, Wallen T, Kumusoglu D, Meister $\mathrm{D}$, Chen A, et al. Maternal diet-induced microRNAs and mTOR underlie $\beta$ cell dysfunction in offspring. J Clin Inves. 2014;124(10):4395-15.

34. Goyal R, Goyal D, Leitzke A, Gheorghe CP, Longo LD. Brain renin-angiotensin system: fetal epigenetic programming by maternal protein restriction during pregnancy. Reprod Sci. 2010;17(3):227-11.

35. Indrio F, Martini S, Francavilla R, Corvaglia L, Cristofori F, Mastrolia SA, et al. Epigenetic matters: The link between early nutrition, microbiome, and long-term health development. Front Pediatr. 2017;5:178.

36. Li C, Guo S, Gao J, Guo Y, Du E, Lv Z, et al. Maternal highzinc diet attenuates intestinal inflammation by reducing DNA methylation and elevating H3K9 acetylation in the A20 promoter of offspring chicks. J Nutr Biochem. 2015;26(2):173-10.

37. Kabaran S, Besler HT. Do fatty acids affect fetal programming? J Health Popul Nutr. 2015;33:14.

38. Lee H-S, Barraza-Villarreal A, Hernandez-Vargas H, Sly PD, Biessy C, Ramakrishnan U, et al. Modulation of DNA methylation states and infant immune system by dietary supplementation with $\omega$-3 PUFA during pregnancy in an intervention study. Am J Clin Nutr. 2013;98(2):480-7.

39. Borengasser SJ, Zhong Y, Kang P, Lindsey F, Ronis MJJ, Badger TM, et al. Maternal obesity enhances white adipose tissue differentiation and alters genome-scale DNA methylation in male rat offspring. Endocrinology 2013;154:4113-12.

40. Zhang P, Torres K, Liu X, Liu C-g, E Pollock R. An overview of chromatin-regulating proteins in cells. Curr Protein Pept Sci. 2016;17(5):401-9. 